\title{
Properties of Resistance Spot-Welded TWIP Steels
}

\author{
Havva Kazdal Zeytin ${ }^{1}$, Hayriye Ertek Emre ${ }^{2, *}$ and Ramazan Kaçar ${ }^{2}$ \\ 1 TUBITAK MAM, Gebze, Kocaeli 41470, Turkey; havva.zeytin@mam.gov.tr \\ 2 Department of Manufacturing Engineering, Karabuk University, Karabuk 78050, Turkey; \\ rkacar@karabuk.edu.tr \\ * Correspondence: hayriyeertek@karabuk.edu.tr; Tel.: +90-370-433-8210 (ext. 1091) \\ Academic Editors: Halil Ibrahim Kurt, Adem Kurt and Necip Fazil Yilmaz \\ Received: 31 October 2016; Accepted: 16 December 2016; Published: 11 January 2017
}

\begin{abstract}
High manganese TWIP (twinning-induced plasticity) steels are particularly attractive for automotive applications because of their exceptional properties of strength combined with an excellent ductility. However, the microstructure and properties of TWIP steels are affected by excessive thermal cycles, such as welding and heat treatment. This paper deals with characterization and understanding the effect of welding current and time on the mechanical properties and microstructure of the resistance spot welded TWIP steel. For this purpose, weld nugget diameter was evaluated and the hardness, tensile shear strength of the weldment, and failure mode of samples were also determined. It has been found that the tensile shear strength of the samples increased with increasing welding current and welding time without expulsion, which reduces the strength of the weldment. Tensile shear samples failed by a partial interfacial fracture mode for low-heat input welds. The pullout fractures were observed with a sufficient heat input without expulsion.
\end{abstract}

Keywords: TWIP steel; welding parameters; resistance spot weld; mechanical properties; microstructure

\section{Introduction}

There is an increasing demand for high strength steel sheets in the automotive industry in order to improve the fuel efficiency, occupant's safety, and reduction of auto body weight [1]. More commonly used advanced high strength steels (AHSS) are dual phase (DP), transformation induced plasticity (TRIP), and twinning-induced plasticity (TWIP). TRIP and TWIP are highly-deformable steels that give them certain amounts of plasticity for machine pressing with a useful hardening characteristic in the event of an accident. These attractive properties stem from a fully-austenitic structure and sufficient principal glide plane symmetry, known as the "twinning-induced plasticity" (TWIP) effect [2]. Several alloying concepts for TWIP steels have been developed and published and the most popular ones are based on the Fe-Mn-C [3,4] or Fe-Mn-Al-Si [5,6] systems.

Resistance spot welding is an assembly process widely used in the automotive industry for joining steel sheet components. Generally, there are three measures for the quality evaluation of resistance spot welds, including physical weld attributes, mechanical properties, and failure mode $[1,7,8]$. Due to high alloying content of AHSS, which influences the heat generation during resistance spot welding, high alloying content increase the bulk resistivity of the metal, which leads to excessive heat at the interface and, therefore, suitable current range shifts to the lower current side. The failure mode of spot welded AHSS's are often the interfacial mode [9].

Spena et al. [10] carried out a preliminary study on the effects of the main important process parameters (welding time, welding current, and clamping force) on the mechanical and microstructural properties of resistance spot-welded TWIP sheets (with $22.4 \%$ Mn content) of $1.4 \mathrm{~mm}$ thickness with using the L-9 $\left(3^{3}\right)$ orthogonally array. They noted that the tensile shear strength of the welded joints 
mainly increases as the welding current increases without any expulsion. Their study show that there is an almost linear relationship between the tensile shear strength and the weld spot size that can be defined for the samples that failed with an interfacial fracture [10]. Saha et al. [11] conducted a study on resistance spot welded high-Mn (18\% Mn) TWIP steels with $1.4 \mathrm{~mm}$ thickness. They confirm that due to high chemical composition in high-Mn steels; expulsion occurred earlier and high welding current increases the cracking tendency because of increasing nugget pressure and the tensile stress in heat affected zone (HAZ) during cooling [11]. Deformation behavior of high-manganese TWIP steels has been widely studied in relation to microstructure and texture evolution by microscopy analysis scanning electron microscope (SEM) and transmission electron microscopy (TEM), X-ray diffraction (XRD) measurements [2,12-21]. However, weldability of such steel has been poorly investigated. Due to insufficient knowledge available regarding the resistance spot weldability of TWIP steel, it is still not widely accepted by automobile industries [9].

In this work, the effects of welding parameters, such as welding current and welding time, on the mechanical properties and metallurgical characterization of spot-welded high $\mathrm{Mn}$ and $\mathrm{Al}$ (32\% Mn, $3.16 \% \mathrm{Al}$ ) TWIP steel in $1 \mathrm{~mm}$ thickness is investigated in detail. For this purpose, the microstructure of welded samples are evaluated and tensile shear load bearing capacity, failure mode, and hardness distribution of weldment are determined for weld quality.

\section{Materials and Methods}

In this study, high-Mn-Al (TWIP) steel which was manufactured experimentally, having a chemical composition of $0.024 \%$ C, 32\% Mn, 2.36\% Si and 3.16\% Al, Bal. \% Fe with minor alloying elements $(<0.01 \%$ B) was used. The bulk specimens were cut into samples with dimensions of $100 \mathrm{~mm} \times 25 \mathrm{~mm} \times 1 \mathrm{~mm}$ and were cleaned with ethanol to remove dirt and surface oil prior to joining (Figure 1).

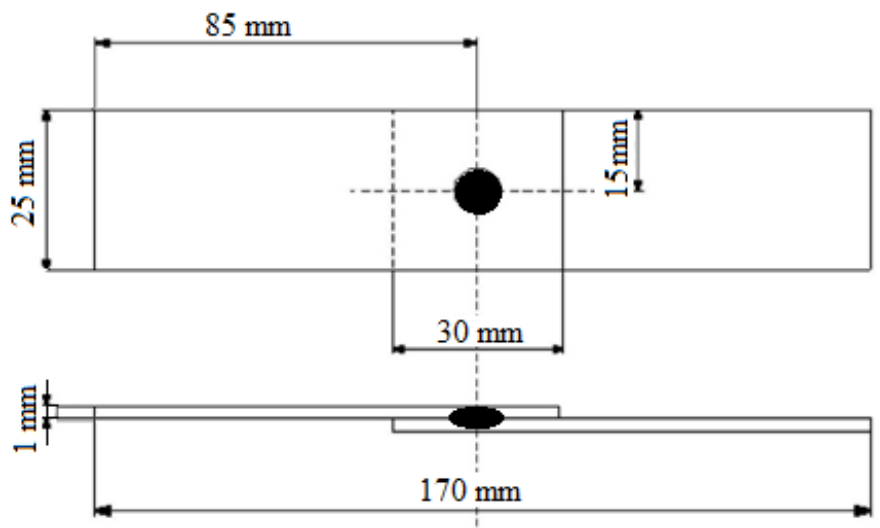

Figure 1. Geometry of the resistance spot-welded tensile shear test specimen.

Test samples were resistance spot welded using a pneumatic, phase-shift-controlled AC spot welding machine with a capacity of $60 \mathrm{kVA}$. The water-cooled F16 type $\mathrm{Cu}-\mathrm{Cr}$ alloy spherical head electrode was employed for joining process. A set of samples were spot welded at a constant welding time with various welding currents. However, the other set of samples was welded at a selected welding current of $7 \mathrm{kA}$ which gave the optimum tensile strength for various welding times. The welding parameters were given in Table 1.

Tensile shear load bearing capacity of weldment was determined by subjecting the specimens to tensile testing at ambient temperature. Three tensile shear test samples were prepared and tested for each of the weld variables by using a Shimadzu testing machine ((Shimadzu Sanjo Works, Kyoto, Japan). The information about thetensile shear test sample has been given in Figure 1. The tensile shear test was performed at a crosshead speed of $5 \mathrm{~mm} / \mathrm{min}$. 
A welded sample was cross-sectioned through the center of the weld nugget for metallographic evaluation and hardness measurements. The test sample was mounted, ground, polished, and finally electrically etched in a solution containing $10 \% \mathrm{HNO}_{3}$ and $90 \%$ water for $2 \mathrm{~s}$ and then etched in a solution containing 3\% $\mathrm{HNO}_{3}$ and $97 \%$ ethanol for $2 \mathrm{~s}$ (3\% nital solution). Optical examination of specimens was carried out by using a Nikon DIC microscope (Nikon Instruments, Karfo-Karacasulu Dis. Tic. A.S., Istanbul, Turkey) and Zeiss Ultra Plus type SEM microscope (Leibniz Institute for Solid State and Materials Research, Helmholtzstraße, Dresden).

Table 1. Welding parameters.

\begin{tabular}{cccccc}
\hline $\begin{array}{c}\text { Welding Current } \\
(\mathbf{k A})\end{array}$ & $\begin{array}{c}\text { Electrode Force } \\
(\mathbf{k N})\end{array}$ & $\begin{array}{c}\text { Weld Time } \\
\text { (Cycle) }\end{array}$ & $\begin{array}{c}\text { Holding Time } \\
\text { (Cycle) }\end{array}$ & $\begin{array}{c}\text { Squeeze Time } \\
\text { (Cycle) }\end{array}$ & $\begin{array}{c}\text { Clamping Time } \\
\text { (Cycle) }\end{array}$ \\
\hline 3 & & & & & \\
5 & 6 & 20 & 20 & & \\
7 & & & & & \\
9 & & 5 & & \\
& & 10 & 20 & & \\
7 & 6 & 20 & & & \\
& & 25 & & \\
\end{tabular}

Note: $(1$ cycle $=0.02 \mathrm{~s})$.

The Vickers microhardness measurement was carried out on a diagonal length to the weld nugget, heat-affected zone, and base metal with a load of $500 \mathrm{~g}$ and a loading time of $10 \mathrm{~s}$ (Figure 2).

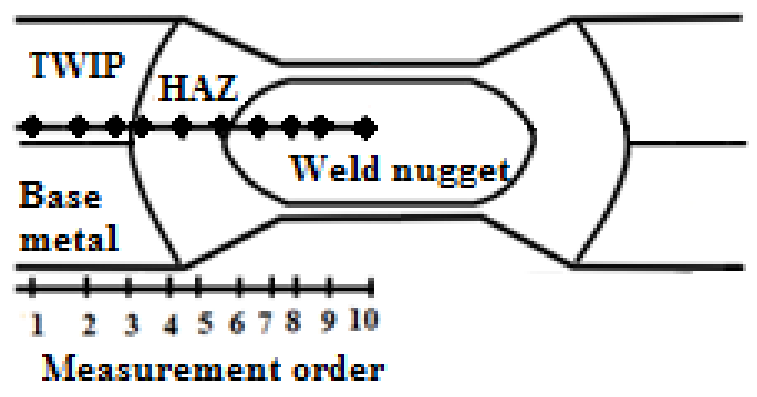

Figure 2. Schematic illustration of hardness measurements.

\section{Results and Discussions}

\subsection{Fracture Characteristics of Sample}

The failure of the resistance spot welded sample occurs generally in three modes: pull-out failure (PF), partial interfacial failure (PIF), and interfacial failure (IF) [22-24]. These main failure mechanisms and failure zones are: (as identified and reported by Choa et al. [25]) (i) strain localization in the base metal/subcritical HAZ; and (ii) ductile shear at the interface in the weld nugget. In general, the maximum tensile shear strength is obtained when the nugget tears from the sheet [26]. An effect of welding parameters on the failure mode of tensile shear test samples is shown (Figure $3 a, b$ ).

As seen in Figure 3a,b, the tensile shear tested sample failed in PIF mode from HAZ through the weld nugget made with a low heat input (at $3 \mathrm{kA}$ welding current and from five to 15 cycles welding time). The detailed fracture surface of the sample that failed in PIF mode is shown in Figure 4a-d. As seen in Figure $4 a, b$, the crack initiated at the steel sheet/steel sheet interface and propagated along the weld nugget circumference in PIF failing mode [11]. Figure 4c,d shows the PIF mode with ductile characteristics in the weld nugget periphery. In the case of lack of defects, cracks normally initiated 
at the edge of weld nugget or in the HAZ (Figure 4e,f). The primary cause of weakening of the weldment may be identified as the second phase or precipitate phases in the HAZ, which may weaken the transition zone from weld nugget and HAZ and grain growth occurred in HAZ adjacent to the weld nugget.
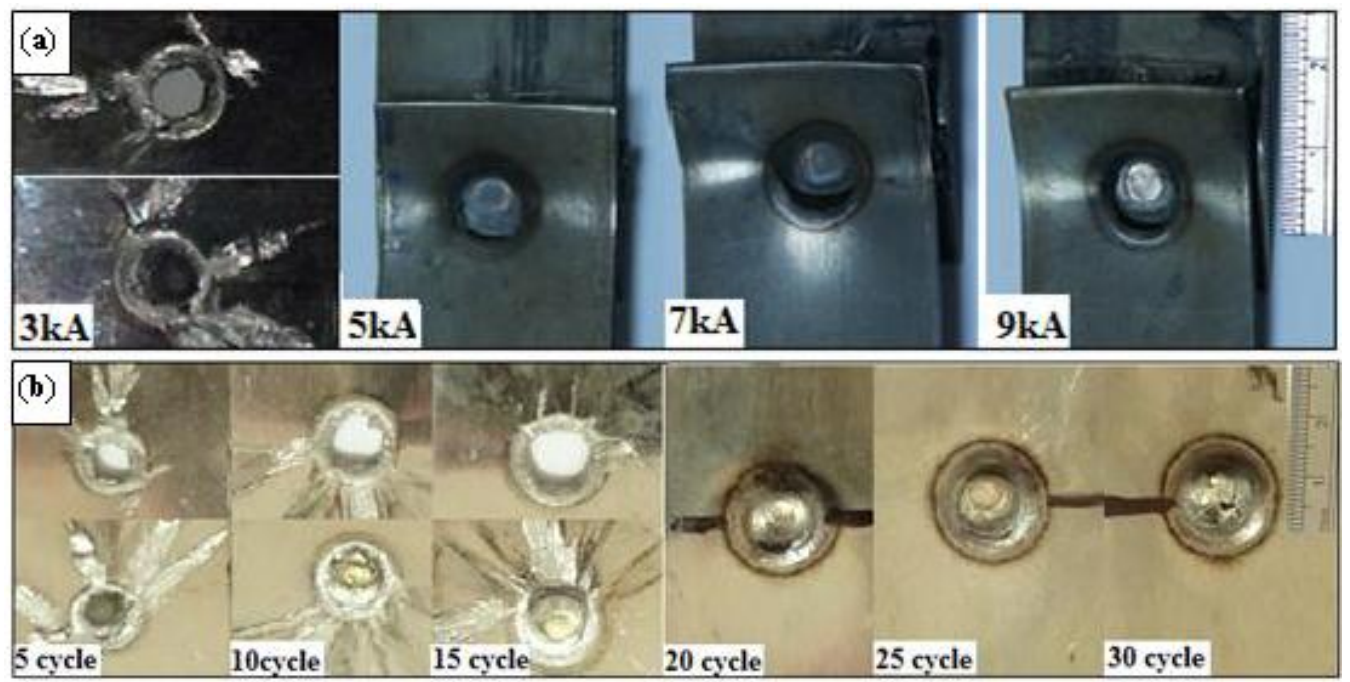

Figure 3. Failure mode of welded samples: (a) constant welding time for various welding currents; and (b) constant welding current for various welding times.
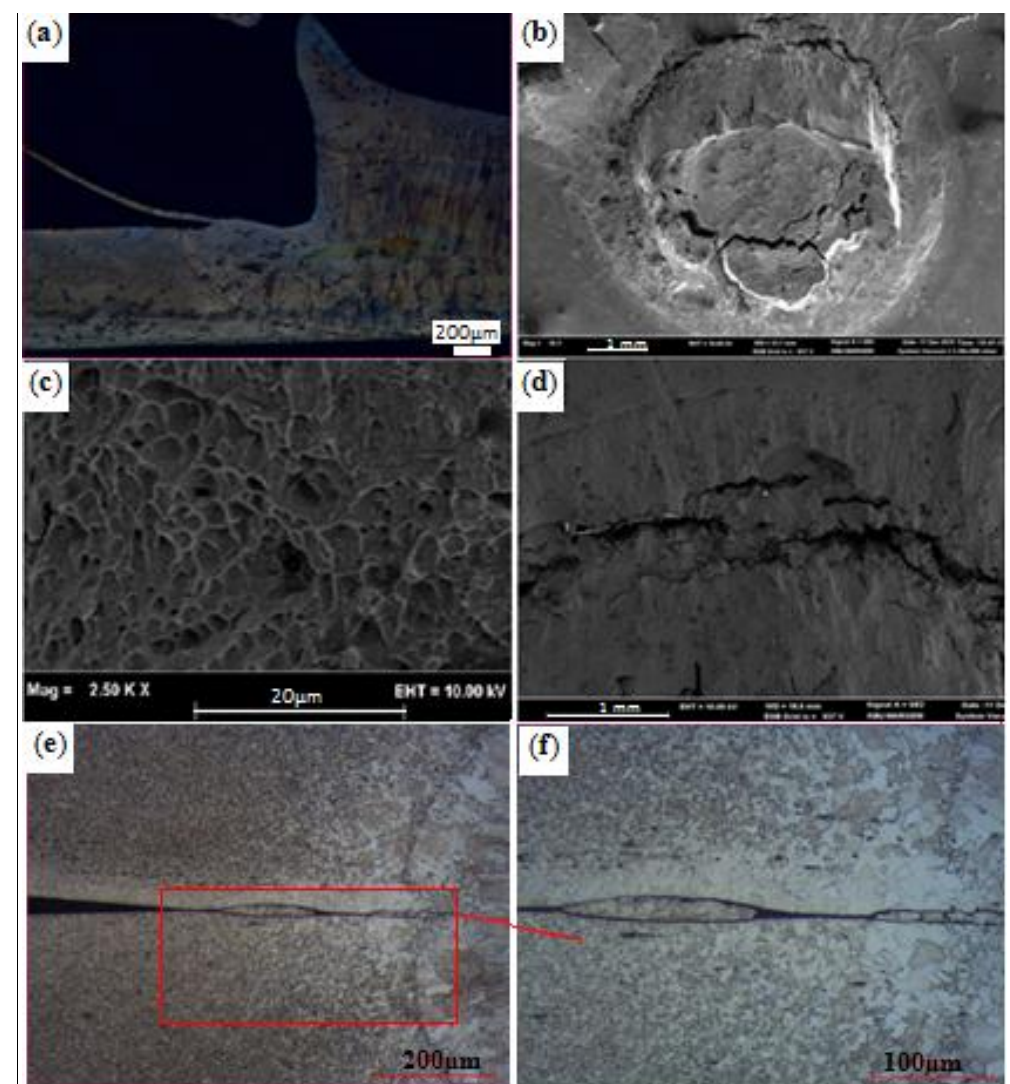

Figure 4. PIF mode of a spot-welded sample: (a) PIF; (b) macrograph of weldment; (c) fracture in weld nugget; (d) HAZ; (e) microstructure of HAZ; (f) high magnification of HAZ microstructure 
Transition from PIF to PF mode depends on the physical characteristics, strength of the crack initiation zone, and especially the weld nugget sizes $[11,27,28]$. In this study, the transition from PIF to PF failure mode was observed for tensile shear tested samples which were joined with higher than $5 \mathrm{kA}$ welding current and 15 cycles welding time. The desired PF mode occurred along the circumference of the weld nugget in the samples which were joined with from $5 \mathrm{kA}$ to $9 \mathrm{kA}$ welding current and 20-25 cycles welding time. The PF mode can be attributed to the strain concentration and grain growth in HAZ, which can encourage the starting of failure from this region [24]. Circumferential failure can be seen under pure opening loading conditions (with a loading angle of $0^{\circ}$ ) as defined in Lin et al. [28]. The strength of the region where failure occurred is important for the tensile shear load bearing capacity of weldment [29]. Expulsion of molten metal was observed for all welding parameters. However, it is believed that the low amount of expulsion did not affect the enlargement of the nugget size and tensile shear strength of the weldment up to the $7 \mathrm{kA}$ welding current and 25-cycle welding parameters. A high amount of expulsion of molten metal from the fusion zone was observed in high welding parameters (over $7 \mathrm{kA}$ welding current and 25 cycles of welding time) with respect to the high input or electrode pressure.

Due to excessive heat input and consequently higher electrode/sheet interface temperature, the amount of plastic deformation in the sheet surface under the applied electrode force is amplified, resulting in excessive electrode indentation [30]. It is believed that the excessive electrode indentation induced a surface crack which is shown in Figure $3 b$ ( 30 cycles of welding time).

\subsection{Effect of Welding Parameters on Weld Nugget Size, Strength, and Hardness}

The most important factors that affect spot weld quality are weld nugget size, strength and ductility, surface appearance, weld penetration, and internal discontinuities [23]. The relationship between welding parameters and weld nugget size, as well as tensile shear strength, is determined and shown graphically in Figure 5a,b.
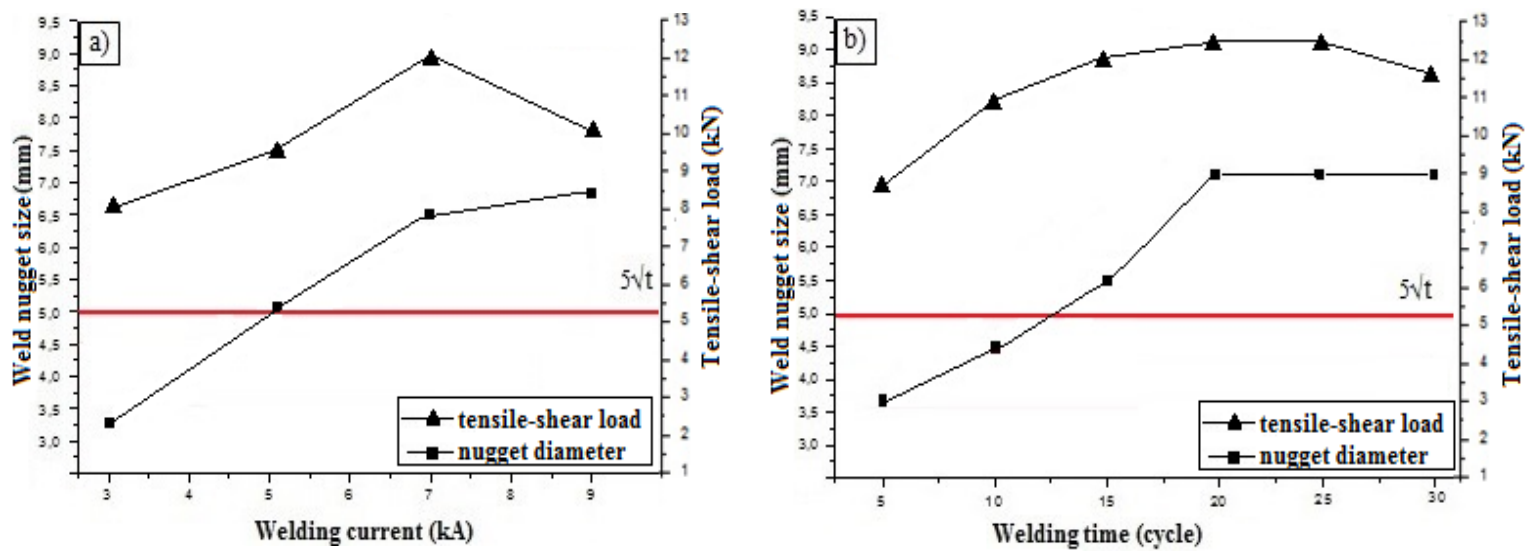

Figure 5. Effect of (a) welding current; and (b) welding time on weld nugget size and tensile shear strength of samples.

The quality and approximate strength of the weldment can be estimated by measuring the nugget diameter of fusion $[23,26]$. The weld nugget size depends on materials type and electrode geometry, which is associated with welding parameters such as welding current and welding time. The diameter of the fused zone must meet the requirements of the appropriate specifications or the design criteria. Normally, the spot weld that is reliably reproduced under normal production conditions should have a minimum weld nugget size of the 3.5-4 times the thickness of the thinnest outside part of the joint [26]. The measured weld nugget size is determined approximately 5-7 times of the thickness of the thinnest outside part of the joint which were welded with over $5 \mathrm{kA}$ welding current (Figure 5a) and 15 cycles of welding time (Figure $5 b$ ). 
Normally, the weldable current and time ranges is determined using the equation $4 \sqrt{ } t$ (where $t$ is the thickness of used steel) condition. However, in AHSS steel welds, in order to ensure the PF mode, a larger weld nugget diameter than the value recommended $4 \sqrt{ } t$ is required [31]. Kumar Pal and Bhowmick [32] showed that the average weld nugget diameter should be equal to or larger than $4 \sqrt{ } t$ for PF mode in dual-phase steels for sheet thicknesses less than $1.5 \mathrm{~mm}$. In this study, the recommended nugget diameter is found to be $5 \sqrt{ } t$ to obtain the desired PF mode for TWIP spot weldment. The results also confirm that weld nugget size clearly increased with increasing heat input up to a critical level. Increasing welding current and welding time causes enhancement of heat input which, in turn, increases the extent of the nugget size of the weldment [9,33-35].

As seen in Figure 5, the tensile shear strength of a sample that was joined with $7 \mathrm{kA}$ welding current for 20 and 25 cycles of welding time, reached the maximum value. With an increase of welding current from $3 \mathrm{kA}$ to $7 \mathrm{kA}$, the strength of the weldment increased from $8 \mathrm{kN}$ to $12 \mathrm{kN}$ due to the enlargement in weld nugget size, which is determined to be $3.8 \mathrm{~mm}$ and $7.2 \mathrm{~mm}$, respectively. Since excessive grain growth in HAZ and high heat generation at the sheet interface led to early expulsion, the strength of the welded sample, which was joined at $9 \mathrm{kA}$, declined to $10 \mathrm{kN}$. Due to high expulsion, the strength of the weldment also decreased for a higher welding time (over 25 cycles). Although the weld nugget diameter, which is $7.8 \mathrm{~mm}$, did not change much by increasing welding times from 15 to 35 cycles, the nugget cross-section $(0.8 \mathrm{~mm})$ thickness slightly decreased. In fact, when the heat input is relatively sufficient, the contact surfaces of two TWIP sheets are completely melted to form the weld nugget. The contact surface area increases with increasing welding parameters, such as welding current and welding time, so the weld nugget size also increases. On the other hand, due to the expulsion of molten metal from the fusion zone, the thickness of the nugget cross-section decreases. Figure $5 b$ indicates that the tensile shear strength of the welded sample increases with increasing welding parameters up to $7 \mathrm{kA}$ welding current and 25 cycles of welding time. However, the strength of the weldment decreases by excessive heat input (over $7 \mathrm{kA}$ welding current and 25 cycles of welding time) due to high expulsion of molten metal from the fusion zone, and decreasing cross-section thickness of the weldment. Spena et al. [10] indicate that there are several industrial standards in which the recommend minimum tensile shear strength of a spot weld for a specific sheet metal are given. The acceptable tensile shear strength (TSS) of a RSW-welded joint, computed as a function of the tensile strength (UTS) and thickness ( $t$ ) of the base metal, is:

$$
\mathrm{TSS}=\left[\left(-6.36 \times 10^{-7} \times \mathrm{UTS}+6.58 \times 10^{-4} \times \mathrm{UTS}+1.674\right) \times S \times 4 \times t^{1.5}\right] / 1000
$$

For the examined TWIP sheet ( $1 \mathrm{~mm}$ thickness, $697 \mathrm{MPa}$ tensile strength), the acceptable tensile shear strength is $9766 \mathrm{~N}$. Therefore, except $3 \mathrm{kA}$ and $5 \mathrm{kA}$ welding current for 20 cycles of welding time and $7 \mathrm{kA}$ welding current for five cycles of welding time, all of the combinations of the welding process parameters in this study provide acceptable tensile strength for the automotive industry. However, because of high expulsion caused an excessive thinning in the weld nugget cross-section height, greater than 25 cycles of welding time for $7 \mathrm{kA}$ welding current, should not be recommended for this sample. In addition, cracks along the periphery of the weld nugget also decreases the strength of the weldment.

Based on the facts mentioned above, it could be concluded that welding current and welding time alters the weld nugget size, which is the main controlling factor for shear strength of the weldment. As also mentioned earlier, tensile shear strength of a spot-welded sample is primarily affected by the strength of the failure region $[28,36]$. Some researchers were also reported that nugget size increases with increasing heat input, hence, the strength of weldment increases [10,29].

Conclusively, the optimum welding parameters resulted in maximum joint strength was established at $7 \mathrm{kA}$ welding current for 20-25 cycles of welding time. Test results clearly point out that heat input is related to the welding current and welding time has an obvious effect on the tensile shear strength of the weldment, and there is a critical heat input level related to welding parameters with which the mechanical properties of the welded joint attain their optimum values. 
The results also point out that an effect of twinning-induced plasticity in the austenitic structure is completely lost in the weld nugget due to melting. It is partially lost in HAZ because of recrystallization and grain growth which decreases the failure location strength.

Hardness measurement was also performed diagonally in the weld nugget, HAZ, and base metal of the weldment and the results are shown graphically in Figure 6.

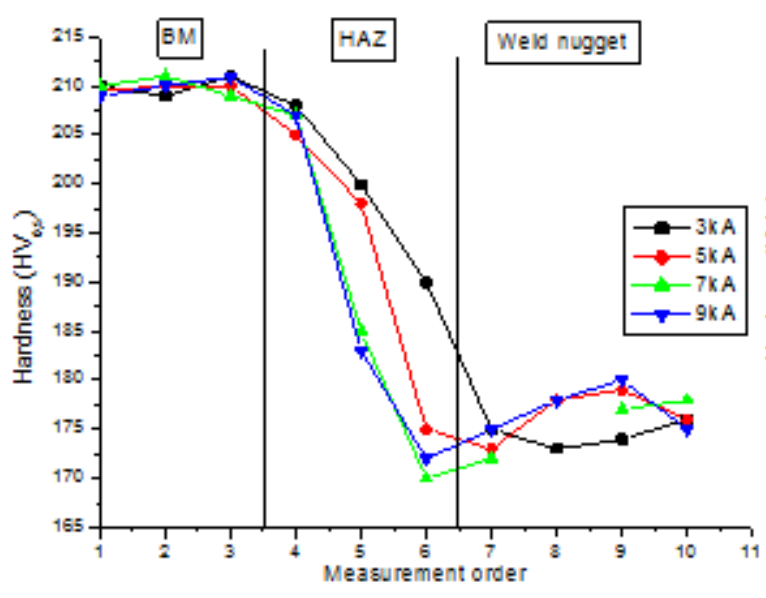

(a)

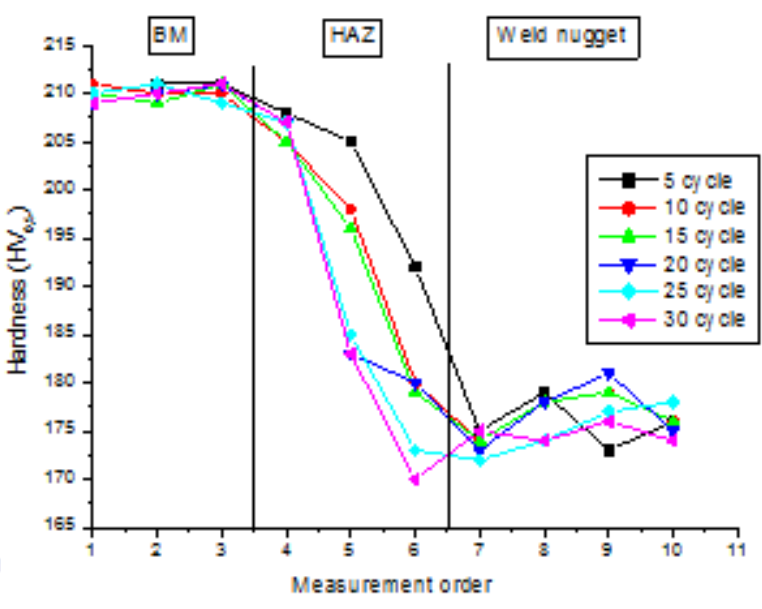

(b)

Figure 6. The hardness of weldment versus: (a) welding current; and (b) welding time.

As seen in Figure 6a,b, the weld nugget and HAZ present considerably lower hardness as compared with base metal. Hardness results also indicate that twinning-induced strength in austenitic structure is completely lost due to melting, but it is partially lost in HAZ due to recrystallization and grain growth. The lower hardness in the weld nugget can also be explained by a lower amount of carbon. Weld nugget hardness for all test samples was found to be similar due to the nature of high-manganese austenitic (TWIP) steel structure that cannot be hardened by heat treatment.

The maximum hardness in HAZ is determined in samples which were welded by using $3 \mathrm{kA}$ welding current for 20 cycles of welding time or $7 \mathrm{kA}$ welding current for five cycles welding time, respectively (Figure 6a,b). The hardness in HAZ decreases by increasing the welding parameters. This could be attributed to high heat input that causes enlargement of HAZ, grain growth, and partial loss of the twinning-induced plasticity.

\subsection{Microstructure Evaluation of Weldment}

The microstructure of the weldment is shown in Figure $7 \mathrm{a}-\mathrm{d}$.

The weld nugget is decorated by a columnar austenite grain which consists of different dendritic structures with directional solidification toward the center of fusion zone (Figure 7a,b). In other words, the equiaxed austenite grains transformed to columnar dendritic morphology in the fusion zone due to the weld thermal cycle (Figure 7e,f). It is well known that microstructure change from the fusion zone towards the base metal depends on the highest temperature reached at each region. It was reported that the dendrites in the fusion zone initially grow as primary arms and, depending upon the cooling rate, composition, and agitation, secondary arms grow outward from the primary arms. The tertiary arms grow outward from the secondary arms. The equiaxed dendrites, which were only present at the center of the fusion zone and totally absent toward approaching fusion line, resulted because of the slow cooling rate at the center of the fusion zone [11].

The microstructure of HAZ is shown in Figure $7 c, d$, in which grain coarsening occurred due to the thermal cycle of the welding process. Since the HAZ has been heated up to temperature approaching the solidus temperature of the alloy, the grain growth is present and many of the second-phase particles, 
which might also be present in the base metal, may dissolve. This can lead to a super-saturation of the austenite matrix during cooling [9]. The microstructure of the TWIP steel is decorated with equiaxed austenite grains as seen in Figure 7d.

In contrast to base metal chemical composition, point EDS analysis carried out in HAZ adjacent to the weld nugget in which $\mathrm{Mn}$ and $\mathrm{Al}$ segregation is attracting attention (Figure 8a-c). It was reported that alloys were segregated according to the condition of equilibrium segregation coefficients; the elements, which have segregation coefficients less than unity, were segregated between the two dendritic cores (interdendritic zone) during solidification [10,37].
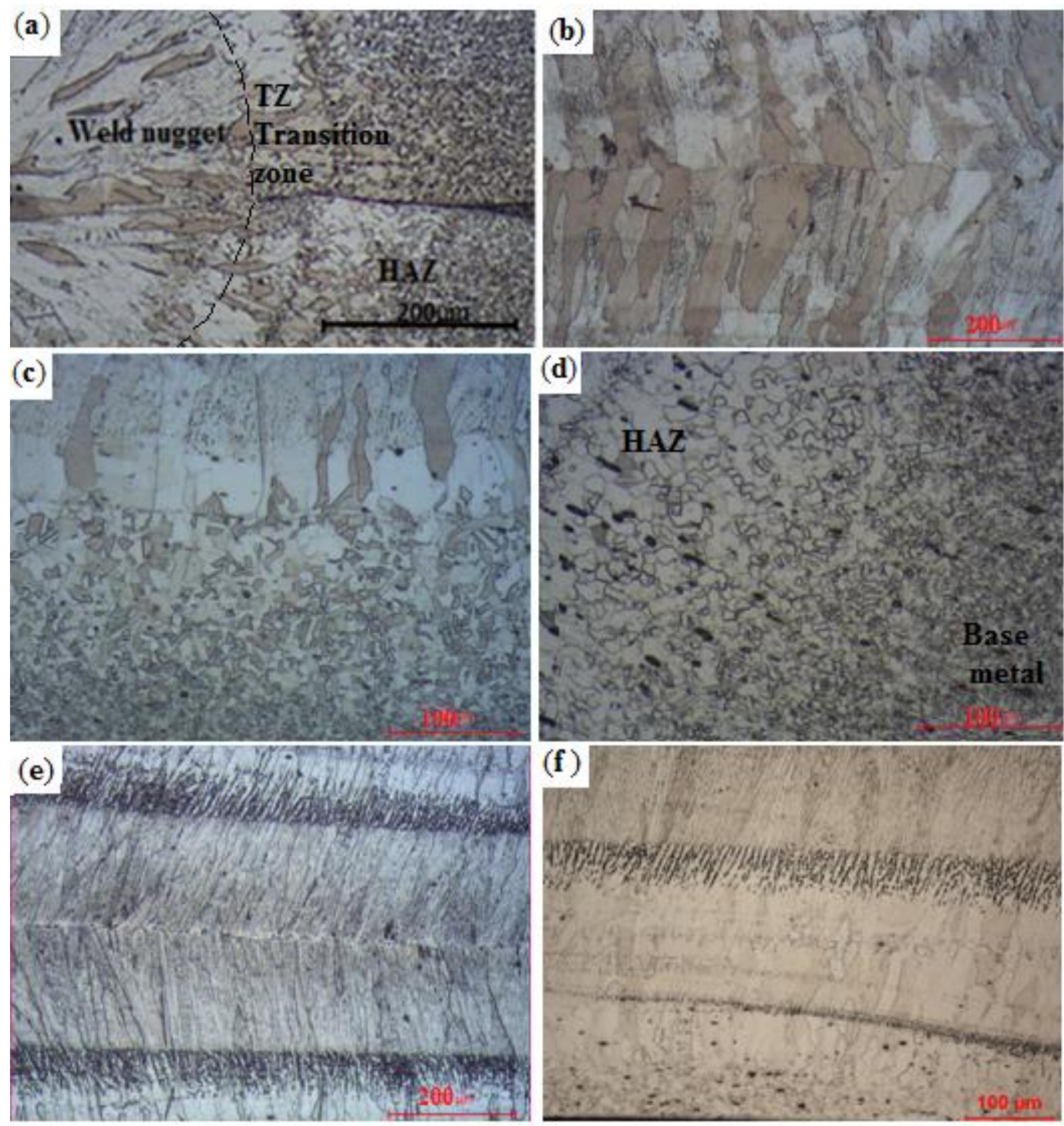

Figure 7. The microstructure of a spot-welded sample: (a) three distinct zones of weldment; (b) fusion zone; (c) transition microstructure from the weld nugget to HAZ; (d) microstructure from HAZ to base metal; and $(\mathbf{e}, \mathbf{f})$ columnar dendrites in the fusion zone. 

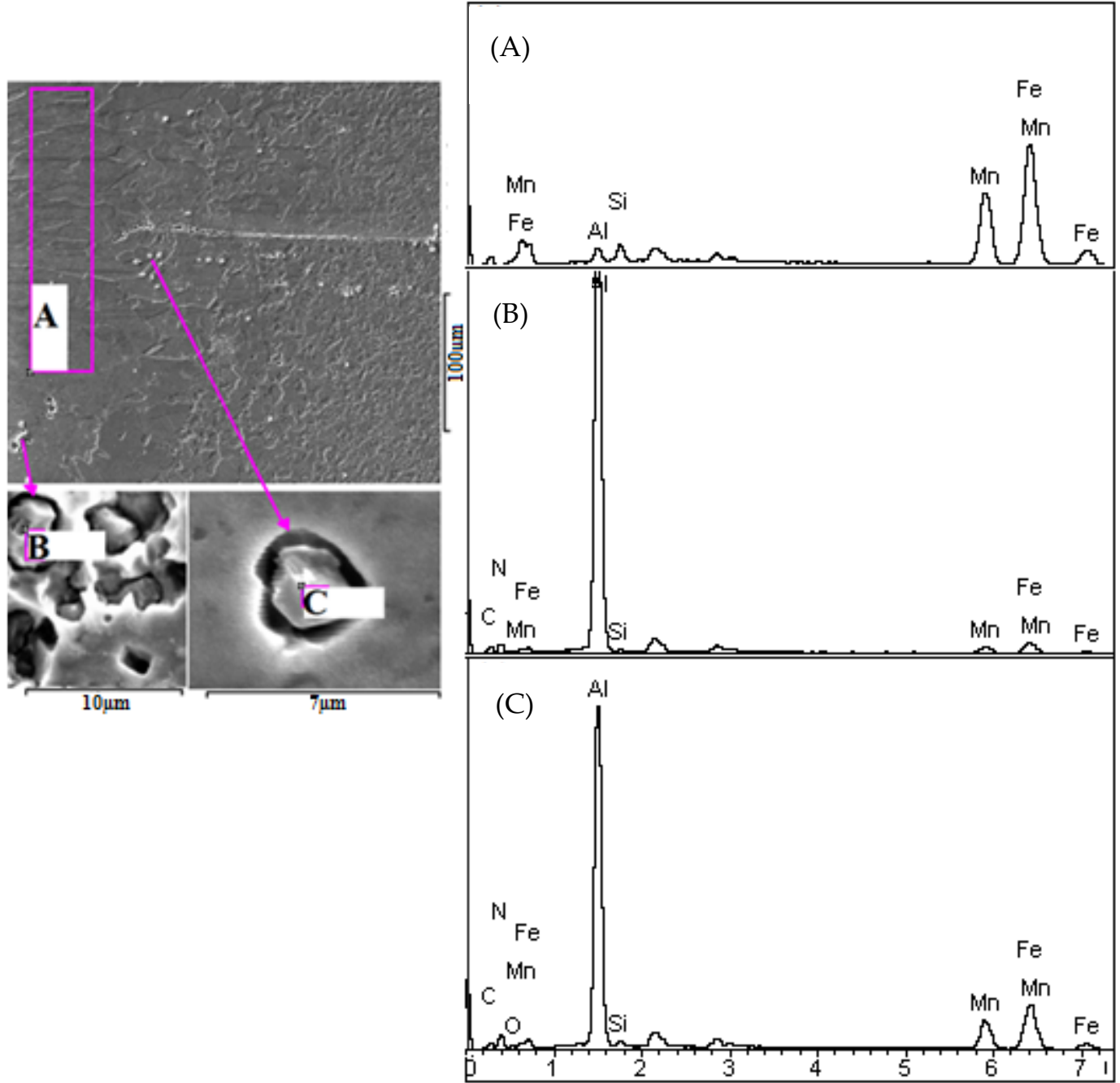

Figure 8. EDS analysis results of welded samples (A) EDS analysis of weld nugget (B) EDS analysis of particles in weld nugget, (C) EDS analysis of particles in HAZ.

The formed particles observed in the transition zone from the weld nugget to HAZ, at which point EDS analysis was carried out (Figure 8b,c), respectively. Results indicate that this formed particles containing high amounts of aluminum. It is thought that alloying element segregation in the transition zone from weld nugget to HAZ can cause the formation of second-phase particles. Saha et al. [11] investigated the element segregation in fusion zone in one of their studies. They reported that $\mathrm{Mn}$ and $\mathrm{C}$ were segregated in interdendritic areas, while $\mathrm{Al}$ was in dendritic areas. This segregated $\mathrm{C}$ and $\mathrm{Mn}$ combine with each other and form MC (metal carbides). It is worth noting that second-phase particles, such as carbide and nitride particles, can inhibit grain growth in steels by hindering the movement of grain boundaries [37,38]. These particles, if not dissolved during welding, tend to inhibit grain growth in the HAZ. Investigation into formed particles should be conducted.

It was observed that the grain size in the weld fusion zone was quite larger than in HAZ and BM. HAZ consists of larger austenitic grains, as compared to those of the base metal, due to the grain coarsening caused by the heat generated during spot welding.

Optical microscopy examination was also carried out to identify internal defects in weld nugget. The appearance, location, and orientation of internal defects are shown in Figure 9a-c. 

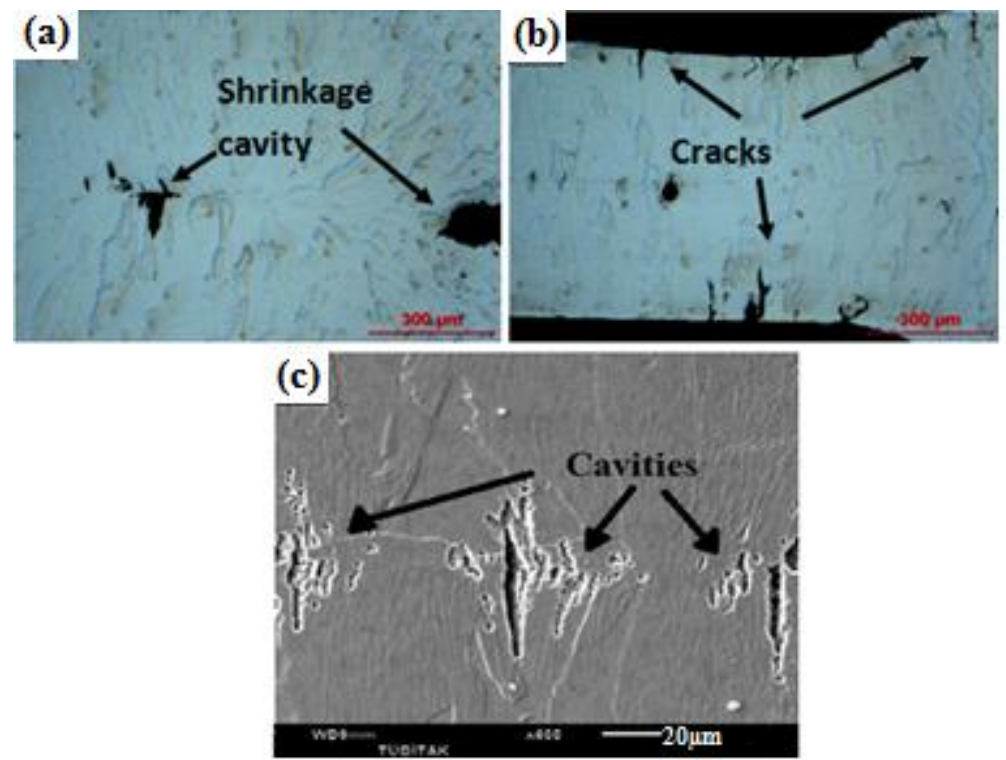

Figure 9. Defects in weld nugget: (a) shrinkage cavity; (b) cracks; and (c) cavities.

As seen in Figure 9a-c, internal defects, such as cavities, are located in the center of the nugget, and cracks are located at the periphery of weld. It is worth noting that the amount of cavities increased with increasing heat input. These internal defects in spot welds are generally caused by low electrode force, high heat input, or any other conditions that produce excessive weld heat. It was reported that these discontinuities will have no detrimental effect on the static or fatigue strength of a weld if they are located entirely in the central portion of the weld nugget because the stresses are essentially zero in the central portion of the weld nugget [25].

The cracks are formed at the periphery of weld nugget due to high heat input (upper than $7 \mathrm{kA}$ welding current and 25 cycles of welding time) followed by a high cooling rate. An increase in the welding current and welding time increases the cracking tendency because of the solidification mode, aluminum segregation, high electrode pressure, and residual stress in the weld nugget during cooling. These cracks can be detrimental for mechanical properties of the weldment where the load stresses are highly concentrated [26].

\section{Conclusions}

The conclusions derived from this study can be given as follows:

- The tensile shear strength of welded samples increased up to $7 \mathrm{kA}$ welding current for 20 cycles of welding time. The results indicate that, except for $3 \mathrm{kA}$ and $5 \mathrm{kA}$ welding current for 20 cycles of welding time and $7 \mathrm{kA}$ welding current for five cycles of welding time, all of the combinations of the welding process parameters in this study provide acceptable tensile strength for the automotive industry. Over the critical heat input level (greater than 25 cycles of welding time for $7 \mathrm{kA}$ welding current) the strength of the welded sample decreases due to expulsion or decreasing in cross-section thickness of the nugget.

- The failure in the tensile shear test sample occurred in PIF mode for lower welding parameters ( $3 \mathrm{kA}$ welding current, up to 15 cycles of welding time). PIF mode was present in the ductile characteristics in the weld nugget. Over these welding parameters (except expulsion) PF mode was started by a crack in HAZ and then the crack propagation occurred by tearing from the sheet. It is thought that the primary cause of weakening in HAZ could be the grain growth mechanism.

- The fully austenitic solidification present in the weld nugget was due to a high amount of manganese and a low amount of carbon in chemical composition. Since the fusion zone 
microstructure has been fully austenitic, the weld thermal cycle has not changed the structure. The ferritic or martensitic transformation has not been detected through metallographic investigation. The formed particles observed in transition zone from the weld nugget to HAZ, at which point EDS analysis was carried out. Results indicate that this formed particle contains high amounts of $\mathrm{Al}$ and $\mathrm{Mn}$ that can be cause the formation of second-phase particles.

- The hardness of the weld nugget and HAZ were found to be lower than those of the base metal due to the nature of the weld thermal cycles, the chemical composition of TWIP steel, and grain coarsening. The hardness results also indicate that the high strength caused by twinning-induced plasticity is almost lost due to the weld thermal cycle.

- Due to electrode force, high heat input, or any other parameters that produce excessive weld heat, the shrinkage cavities and cracks were observed in the fusion zone of the weldment. It is believed that the cracks at the periphery of a weld nugget where the load stresses are highly concentrated were formed due to the solidification mode, interdendritic aluminum segregation, high electrode pressure, and residual stress in the weld nugget.

- In conclusion, the optimum welding parameters that guarantee acceptable tensile shear strength and fracture mode $(\mathrm{PF})$ for the automotive industry were obtained at $7 \mathrm{kA}$ welding current for 20 and 25 cycles of welding time in the examined range. The results indicate that the acceptable welding parameter area is very narrow for resistance spot-welded TWIP steels, because of cracks and cavities in the weld nugget, surface cracks in the HAZ that causes PIF mode, unacceptable weld nugget geometry in adequate welding parameters because of low heat input, and high metal expulsion reducing the partial thickness due to high heat input.

Author Contributions: H.K.Z. produced and provided TWIP steels. R.K. conceived and designed the welding; H.E.E. performed the experiments; H.E.E., H.K.Z and R.K. analyzed the data; R.K. contributed materials and analysis tools; H.E.E. wrote the paper.

Conflicts of Interest: The authors declare no conflict of interest.

\section{References}

1. Poranvari, M.; Mousavizadeh, S.M.; Marashi, S.P.H.; Goodarzi, M.; Ghorbani, M. Influence of fusion zone size and failure mode on mechanical performance of dissimilar resistance spot welds of AISI 1008 low carbon steel and DP600 advanced high strength steel. Mater. Des. 2011, 32, 1390-1398. [CrossRef]

2. Beal, C. Mechanical Behavior of New Automotive High Manganese TWIP Steel in the Presence of Liquid Zinc. Ph.D. Thesis, L'Institut National des Sciences Appliquées de Lyon, Lyon, France, 2011; pp. 1-11.

3. Bouaziz, O.; Allain, S.; Scott, C.P.; Cugy, P.; Barbier, D. High manganese austenitic twinning induced plasticity steels. A review of the microstructure properties relationships. Curr. Opin. Solid State Mater. Sci. 2011, 15, 141-168. [CrossRef]

4. Frommayer, G.; Brüx, U.; Neumann, P. Supra-ductile and high-strength manganese-TRIP/TWIP steels for high energy absorption purposes. ISIJ Int. 2003, 43, 438-446. [CrossRef]

5. Grässel, O.; Krüger, L.; Frommeyer, G.; Meyer, L.W. High strength Fe-Mn-(Al, Si) TRIP/TWIP steels development-Properties-Application. Int. J. Plast. 2000, 16, 1391-1409. [CrossRef]

6. Roncery, L.M.; Weber, S.; Theisen, W. Welding of twinning-induced plasticity steels. Scr. Mater. 2012, 66, 997-1001. [CrossRef]

7. Sawhill, J.M.; Baker, J.C. Spot weldability of high-strength sheet steels. Weld. J. 1952, 31, 931-943.

8. Pouranvari, M.; Abedi, A.; Marashi, P.; Goodarzi, M. Effect of expulsion on peak load and energy absorption of low carbon resistance spot welds. Sci. Technol. Weld. Join. 2008, 13, 39-43. [CrossRef]

9. Chandra Saha, D.; Han, S.; Chin, K.G.; Choi, I.; Park, Y.D. Weldability evaluation and microstructure analysis of resistance-spot-welded High-Mn steel in automotive application. Steel Res. Int. 2012, 83, 1-6.

10. Spena, P.R.; Maddis, D.M.; Lombardi, F.; Rossini, M. Investigation on resistance spot welding of TWIP steel sheets. Steel Res. Int. 2015, 86, 1480-1489. [CrossRef]

11. Saha, D.C.; Cho, Y.; Park, Y.D. Metallographic and fracture characteristics of resistance spot welded TWIP steels. Sci. Technol. Weld. Join. 2013, 18, 711-720. [CrossRef] 
12. Choi, H.C.; Ha, T.K.; Shin, H.C.; Chang, Y.W. The formation kinetics of deformation twin and deformation induced $\varepsilon$-martensite in an austenite FE-C-Mn steel. Scr. Mater. 1999, 40, 1171-1177. [CrossRef]

13. Dai, Q.; Yang, R.; Chen, K. Deformation behavior of Fe-Mn-Cr-N austenitic steel. Mater. Charact. 1999, 42, 21-26. [CrossRef]

14. Vercammen, S.; Blanpain, B.; de cooman, B.C.; Wollants, P. Cold rolling behavior of an austenitic Fe-30Mn-3Al-3Si TWIP-steel: The importance of deformation twinning. Acta Mater. 2004, 52, 2005-2012. [CrossRef]

15. Yang, P.; Xie, Q.; Meng, L.; Ding, H.; Tang, Z. Dependence of deformation twinning on grain orientation in a high manganese steel. Scr. Mater. 2006, 55, 629-631. [CrossRef]

16. Ueji, R.; Tsuchida, N.; Terada, D.; Tsuji, N.; Tanaka, Y.; Takumera, A.; Kunishige, K. Tensile properties and twinning behavior of high manganese austenitic steel with fine-grained structure. Scr. Mater. 2008, 59, 963-966. [CrossRef]

17. Barbier, D.; Gey, N.; Allain, S.; Bozzolo, N.; Humbert, M. Analysis of the tensile behavior of a TWIP steel based on the texture and microstructure evolutions. Mater. Sci. Eng. A 2009, 500, 196-206. [CrossRef]

18. Bracke, L.; Verbeken, K.; Kestens, L.; Penning, J. Microstructure and texture evolution during cold rolling and annealing of high Mn TWIP steel. Acta Mater. 2009, 57, 1512-1524. [CrossRef]

19. Idrissi, H.; Ryelandt, L.; Veron, M.; Schryvers, D.; Jacques, P.J. Is there a relationship between the stacking fault character and the activated mode of plasticity of Fe-Mn based austenitic steels. Scr. Mater. 2009, 60, 941-944. [CrossRef]

20. Dai, Y.J.; Tang, D.; Mi, Z.L.; Li, J.C. Microstructure characteristics of an Fe-Mn-C TWIP steel after deformation. J. Iron Steel Res. Int. 2010, 17, 53-59. [CrossRef]

21. Idrissi, H.; Renard, K.; Ryelandt, L.; Schryvers, D.; Jacques, P.J. On the mechanism of twin formation in Fe-Mn-C TWIP steels. Acta Mater. 2010, 58, 2464-2476. [CrossRef]

22. Gutierrez-Urrutia, I.; Zaefferer, S.; Raabe, D. The effect of grain size and grain orientation on deformation twinning in a Fe-22 wt.\% Mn-0.6 wt.\% C TWIP steel. Mater. Sci. Eng. A 2010, 527, 3552-3560. [CrossRef]

23. Kearns, W.H. Metals and their weldability. In AWS Welding Handbook, 7th ed.; American Welding Society: St. Doral, FL, USA, 1982; Volume 4, pp. 76-146.

24. Santella, M.L.; Babu, S.S.; Riemer, B.W.; Feng, Z. Influence of microstructure on the properties of resistance spot welds. In Proceedings of the 5th International Conference on Trends in Welding Research, Pine Mountain, GA, USA, 1-5 June 1998.

25. Chao, Y.; Miller, K.; Wang, P.C. Impact strength of resistance spot welded joints. In Proceedings of the WS Sheet Metal Welding Conference VIII, Detroit, MI, USA, 13-16 October 1998; pp. 3-12.

26. Kearns, W.H. Welding Processes. In AWS Welding Handbook, 7th ed.; American Welding Society: St. Doral, FL, USA, 1978; Volume 2, pp. 1-55.

27. Pouranvari, M.; Asgari, H.R.; Mosavizadch, S.M.; Marashi, P.H.; Goodarzi, M. Effect of weld nugget size on overload failure mode of resistance spot welds. Sci. Technol. Weld. Join. 2007, 12, 217-225. [CrossRef]

28. Pouranvari, M.; Marashi, S.P. Failure mode transition in AHSS resistance spot welds. Part I. Controlling factors. Mater. Sci. Eng. A 2011, 528, 8337-8343. [CrossRef]

29. Marashi, P.; Pouranvari, M.; Sanaee, S.M.H.; Abedi, A.; Abootalebi, H.; Goodarzi, M. Relationship between failure behavior and weld fusion zone attributes of austenitic stainless steel resistance spot welds. Mater. Sci. Technol. 2008, 24, 1506-1512. [CrossRef]

30. Razmpoosh, M.H.; Shamanian, M.; Esmailzadeh, M. The microstructural evolution and mechanical properties of resistance spot welded Fe-31Mn-3Al-3si TWIP steel. Mater. Des. 2014, 67, 571-576. [CrossRef]

31. Pouranvari, M.; Marashi, S.P. Critical review of automotive steels spot welding: Process, structure and properties. Sci. Technol. Weld. Join. 2013, 18, 361-403. [CrossRef]

32. Kumar Pal, T.; Bhowmick, K. Resistance spot welding characteristics and high cycle fatigue behavior of DP 780 steel sheets. J. Mater. Eng. Perform. 2012, 21, 280-285.

33. Vural, M.; Akkuş, A. On the resistance spot weldability of galvanized interstitial free steel sheets with austenitic stainless steel sheets. J. Mater. Process. Technol. 2004, 16, 53-156. [CrossRef]

34. Sharma, P.; Ghosh, P.K.; Nath, S.K. Fatigue behavior of resistance spot welded Mn-Cr-Mo dual phase steels. Z. Metallkd. 1993, 84, 513-517.

35. Gupta, P.; Ghosh, P.K.; Nath, K.; Ray, S. Resistance spot weldability of plain carbon and low alloy dual phase steels. Z. Metallkd. 1990, 81, 502-508. 
36. Lin, S.H.; Pan, J.; Wu, S.R.; Tyan, T. Spot Weld Failure Loads under Combined Mode Loading Conditions; SAE Technical Paper No. 2001-01-0428; Society of Automotive Engineers: Warrendale, PA, USA, 2001.

37. Kou, S. Welding Metallurgyü, 2nd ed.; Wiley: Hoboken, NJ, USA, 2003; pp. 341-352.

38. Higgins, R.A. Engineering Metallurgy Applied Physical Metallurgy, 6th ed.; Elsevier: Amsterdam, The Netherlands, 1993; pp. 79-99.

(c) 2017 by the authors; licensee MDPI, Basel, Switzerland. This article is an open access article distributed under the terms and conditions of the Creative Commons Attribution (CC-BY) license (http:/ / creativecommons.org/licenses/by/4.0/). 